\title{
ARCHITECTURALLY ARTISTIC METAL OF CITY IVANO-FRANKIVSK (STANISLAVIV), END OF 19TH-BEGINNING OF 20TH CENTURY
}

\author{
Natalia Kachkovska \\ Department of Design and Theory of Art \\ National University named after V. Stefanik \\ Scientific Secretary \\ National preserve "Davniy Halych" \\ 1 Franko str., Galich, Ukraine, 77101
}

\begin{abstract}
In this article we consider a theme concerning the evolution of metal decoration in architecture of the town Ivano-Frankivsk (Stanislaviv), dated XIX - early XX century, this question was analyzed in line with European architectural and artistic trends of that time. Style trends and compositional features were detected through the example of certain types of metal-plastic in the architecture of the town. Special attention was paid to finding ways to preserve valuable historical examples of architectural-artistic metal, which are exposed to destruction.

Ancient metal-plastic, which impresses us by the mastery of far-back blacksmiths, adorns most historic buildings in IvanoFrankivsk (Stanislaviv). It was formed, at each stage of its development, in line with European architectural-artistic trends and reproduces the content of these processes by typological, compositional, stylistic, iconographic, formal features, together with production technique and manufacturing technology. The metal-plastic being a valuable architectural-artistic heritage of XIX - early XX century, which defines the direction of urban modern forging art development, nowadays is exposed to destruction. Undervaluation and low level of research work, concerning Ivano-Frankivsk historic metal-plastic as a cultural heritage object, become one of the reasons that community and some experts do not consider it as an object that influenced the formation of the architectural urban space image and still continues to influence its evolution.
\end{abstract}

Keywords: Ivano-Frankivsk, artistic blacksmithing, ornament, style, blacksmiths' workshops.

\section{Introduction}

Architectural metal plastic of Ivano-Frankivsk from the end of the 19th-beginning of the 20th century is a valuable cultural heritage that influenced the creation of the integrated architectural image of the urban space.Craftsmen of artistic processing of metal were able to naturally connect metal decor with architectural decision by using a certain style. The article's goal is to detect and explore an architectural iron work, as well as recognition of firms and workshops that create artistic metal work of art in order to attract the attention of society to the issue of preserving artistic metal work which is on the brink of extinction.

\section{The purpose of the reseurch}

The purpose of this article is to identify stylistic and compositional features of architecturalartistic metal in town, dated late XIX - early XX century.

\section{Result of the reseurch}

Late XIX - early XX century become a period, which attracts attention by the bright artistic heritage, the variety of architecture and art performances, demonstration of techniques and technologies, in particular architectural-artistic metal as a component of architecture and decorative-ornamental art. Metal decoration played an important role in the architectural image of ancient towns. It reproduced certain style with high expression, for this reason architects have paid much attention to such type of decoration. In the town Stanislaviv the end of XIX - early XX century become a time of highest prosperity of architectural-metal decoration. «Building-fever» of that period stimulated its active use. At that time the town was built especially intensive. Construction of new types of buildings, such as embassy, business unit, affiliates of European institutions, saving banks, bank brunches, private residences, apartment houses, hotels, shops, industrial buildings 
and structures give architects and artists the task to find new representative methods of aesthetic expression. Metal plays the role of decoration and compositional accent or dominant of facade, artistic metal works become a kind of calling card of a building. They played special stylistic and shape-generating role in the interiors of lobbies, staircases, halls.

In the late XIX - early XX century there were few large Galician companies that dealt with artistic metal, whose activities enlarged upon the whole territory of the region. Other locations, smaller one, like workshops, were limited to poor number of work just in local territory. The leading centers, where major companies existed, were Krakow, Lviv, Stanislaviv, Ternopil. Most of them manufactured products in the field of artistic and building locksmith and metalworking [1]. Among them: a leading organization in Eastern Galicia, which expanded its activity to Stanislaviv; architectural design and construction firm, owned by Levynsky I. in Lviv [1]; architectural and construction firm «Serafini», the largest one in Stanislaviv [2-4]; Stanislaviv architectural and construction firm «Inż. Krausz i ska» [2, 4, 5]. Among smaller Stanislaviv companies, that perform work in the field of artistic metal (building and construction companies, locksmith companies, locksmith-artistic-construction firms, manufactories of metal products), we can find: locksmith firm «Beter Leon i ska» [5]; casting shop, turnery shop, yellow metal casting shop owned by Karpshwimmer N [6]; building company «Pezet» [7, 8]; locksmith-artistic-construction workshop, owned by Ian Fedorovsky [9], Peter Yaroshevsky [9, 10] (this company in 1910's, during the reconstruction of saving bank, situated at 14, Mazepy Street, made all metal decoration, such as: entrance door, which still has the stamp of the company, staircase fencing, street lamps); locksmith-artisticconstruction workshop «Vladislav Clemens and Son» [8]; artistic-locksmith workshop, owned by Julian Sherer [7, 8]; locksmith-building workshop, owned by Peter Ruschel, which produced balconies, staircase fencing, portals, doors, windows, fences, bridge fencing, etc.; locksmith workshop by Isaac Kuzhel [11]; Stanislaviv locksmith and metal manufactory «Horodyski Felicyan» with administrative center in Stryi [2]; metal products factory «Silvinia» [7, 8]; mechanical and blacksmith workshop by Adolf Flasher; mechanical workshop by Izak Weitzen [11]; Jaworski R. and Sons Union called «Krai» [6, 8], which produced casting and locksmith products [11]; Antony Shifner workshop [11]. Metal architectural decoration with use of nonferrous metals was produced by casting and machines factory «Viz» [12-14]. All Stanislaviv craft workshops, specializing on the producing of architectural-artistic metal, were merged into two work departments [15].

The impulse, leading to wide use of artistic forging and iron casting, from the late XIX century, was caused by the cheapening of metal and increasing of metal production. The most common, at that time in Stanislaviv, was forging technique, despite the fact that other one were used, such as casting, which was more typical for the middle and second half of the XIX century. In the late historicism, eclecticism and secession epoch, works made in the technique of artistic forging lose difficult detalization, present in previous eras. This is due to the adaptation of welding to the manufacturing process, that simplified connection of metal constructions and forged elements [16].

Artistic forging in European countries at that period massively used various industrial metal profiles and rolled steel. As a result of field surveys concerning artistic forging works, dated late XIX - early XX century and situated in Stanislaviv, we found, that forged architectural details are made mostly of: different sizes square metal profile; metal strips and rods; plate steel, which was used for producing garland elements, flowers, leaves, masks, heraldry elements. We identified several techniques that, in certain combinations, were used for manufacturing of various metal pieces. We are talking about: forging, stamping, embossing, curving, punching. Also we found out methods of steel timbering: welding, riveting (12, Hrushevskoho Street, dated third part of the XIX century), and, in some cases, casting. For the modernist metal architectural details, such as balcony and staircase fencing, small and large diameter tubular structures were used. Most of the metal decoration, dated interwar period (1920-1939), obviously, can be classified as a special type of mass artistic-industrial production and design. For Stanislav, in the context of European development, this period can be identified as industrial design development age, and the biggest part of that time decoration is classified as a typical metal architectural decoration.

Let's try to analyze stylistic spectrum of the elements of metal decoration and formal compositional structure of the brightest examples of the metal structural and decorative plastic on the 
houses. Such survey was done in accordance to each chronological stage and within research period. Also let's try to consider preserved examples dated mid-nineteenth century. Such research will help us to outline creative tradition as well as the appearance of entirely new compositional-stylistic and technological methods in architectural-artistic metal decoration.

1. The earliest, not numerous examples of architectural metal on the historic buildings in town Ivano-Frankivsk, which have survived to this day, are dated 1830's-1870's. We are talking about the brightest examples of classicistic decoration and mature historicism decoration, made by casting, curving, embossing technique, for example balcony fencing in the buildings situated at: the corner of 1, Mazepa Street and Vichevyi Square (dated 1827-30) [17]; 18, Sichovyh Striltsiv Str. (1827, building was demolished in February 2016); 2, Nyzova Str. (1840) [17]; 4, Bachynsky Str. (1870s); 5, Nezalezhnosti Str. (1870s) [18].

The bright examples of classicistic decoration in residential architecture of Stanislaviv are represented by house balconies at: 1, Mazepa Street - Vichevyi Square (dated 1827-1830) with the monogram «SG»; 18, Sichovyh Striltsiv Str. (1827) with the monogram dedicated to the first owner Rehenshtraif S. - «SR» [18]. Balcony fencing on the building situated at 1, Mazepa street are made from rods and strips that form metric design of the fencing, which is decorated with embossed elements in the form of flowers. Balcony fencing on the house at 18, Sichovyh Striltsiv Str. is formed by metric repetition of ovals, which are framed with wide frieze belts with crossed rhombs, made by using of punching technique. On the symmetry axis of the two balconies is placed compositional dominant - monogram, fits in the leafy coronal, made in curving and embossing technique. On the house number 18 at Sichovyh Striltsiv Str. this compositional group is accompanied with winged lions (tetramorph), rested on the coronal. Production technique and decoration character indicate that structural metal-plastic of both buildings was made in one period, probably, by one master.

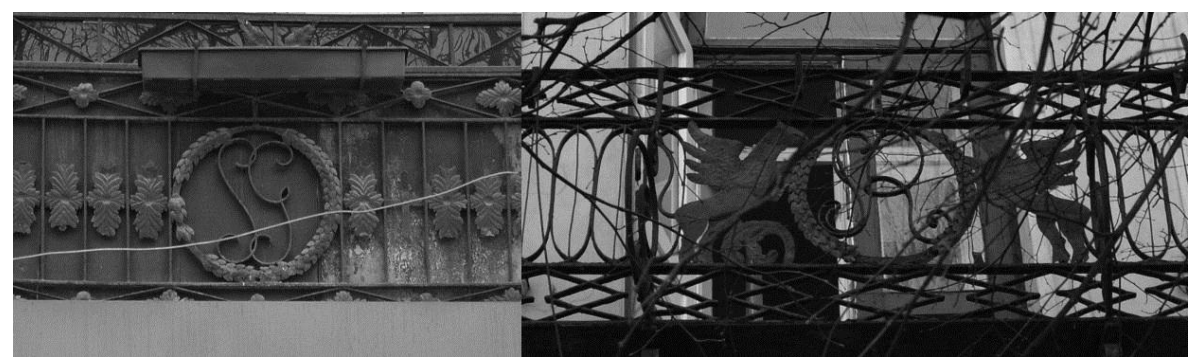

Fig. 1. Balcony fencing on the buildings situated at:

1, Mazepa Str. - Vichevyi Square (1827-1830); 18, Sichovyh Striltsiv Str. (1827)

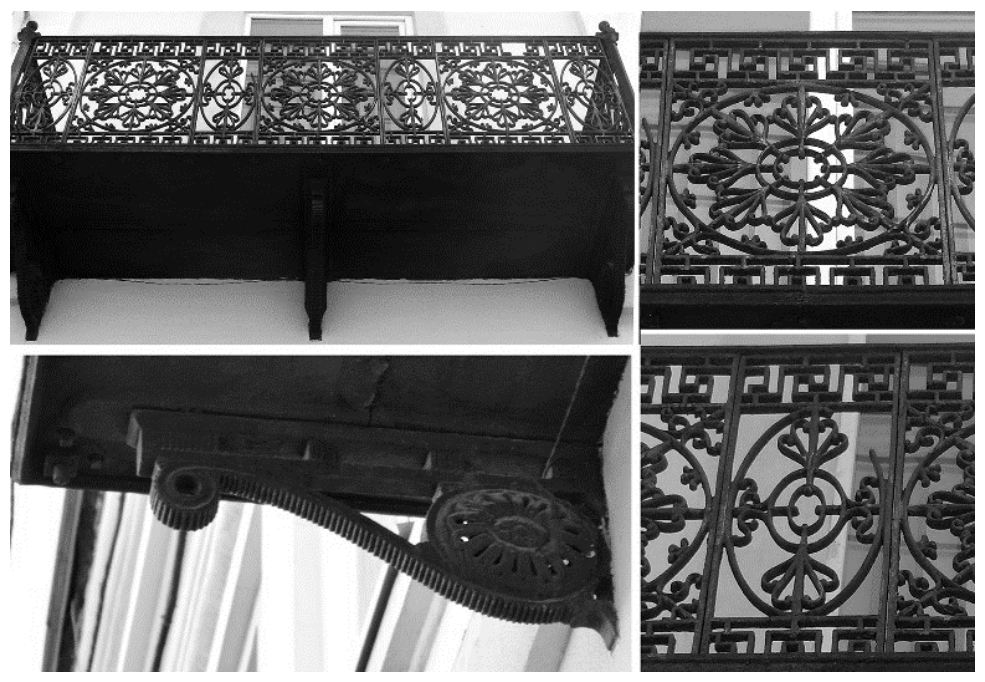

Fig. 2. Balcony fencing and balcony bracket on the building number 2 at Starozamkova Street (1732) 
Traditional classicistic compositional scheme with using of stripe ornament, which includes meander motif, we can observe through the balcony fencing and brackets on the former Trinitarian monastery at 2, Starozamkova Street. (1732). Also this example demonstrates using of the elements of centric symmetry, which is achieved by inscribing identical smaller forms into a large circle or oval shape (borrowed from Baroque).

In the middle and second half of the nineteenth century the influence of stylistic Gothic forms becomes more noticeable. In the iron balcony fencing in Stanislaviv appear new elements: lancet arches and quatrefoils, formed by twisted acanthus halms, at that time halm plastic becomes more refined.

Typical examples of valuable historical metal-plastic of that period, made in the casting technique, is iron cast fencing and balcony brackets on the buildings situated at: 1, Mazepa Str. - Vichevyi Square (1827-1830), 29 Halytska Str. (1835); 2, Bachynsky Str. (1874-1880); 4, Shevchenko Str. (1880-1890); 17, Mazepa Str. (1880).

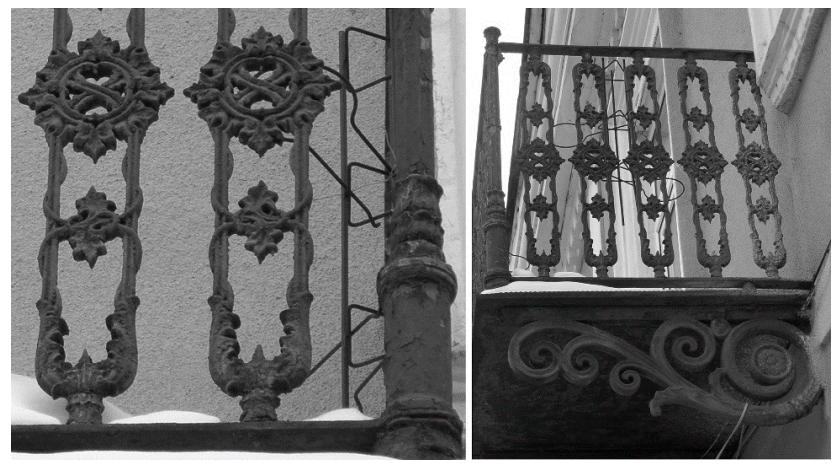

Fig. 3. Cast balcony fencing and brackets on the building situated at 1, Mazepa Str. - Vichevyi Square (dated 1827-1830)

Using of the metal balcony plate was also typical for the nineteenth century (building situated at 18, Sichovyh Striltsiv Str., dated 1827). Sometimes it was decorated, like on the house situated at 5, Nezalezhnosti Str. (1870s), by metal strip, whose main role is constructive, that prevents sinking-down of the balcony plate.

Laconic analysis of the architectural-artistic forging of Stanislaviv while classicistic period gives rise, primarily, to state appearance of such element as balcony on the façade (which become the classicistic innovation) and also to state expansion of ornamental casting technique together with forging.

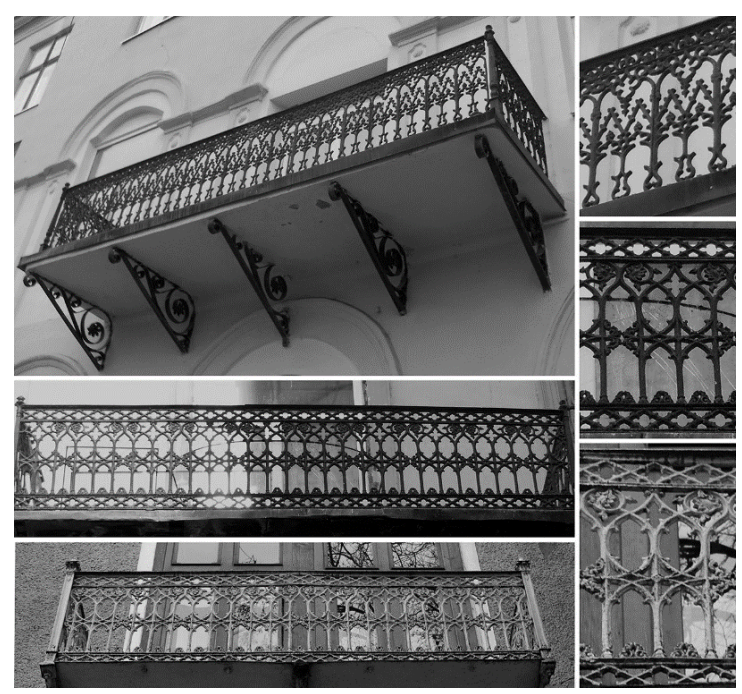

Fig. 4. Cast balcony fencing on the buildings situated at: 29, Halytska Str. (dated 1835); 2, Bachynsky Str. (dated 1874-1880); 4, Shevchenko Str. (dated 1880th) 
Forged metal balcony fencing firs of all is characterized by smooth rods, geometric forms of the ornament elements, combined with floral motifs and bay leaves. Motive is repeated mostly in a manner of translational symmetry along the line.

In the classicistic casting there were used a limited number of geometrical and plant ornament motives. Line, circle, meander, rhombus are the most popular motives together with acanthus and naturalistic floral ornament [19]. Lots of balcony fencing are decorated with halms, waved in volutes (often paired). Middle part of volute was decorated with floral festoon.

Typical features representing composition of classicistic balcony grating are: vertical mirror symmetry, simple geometric repetition, statics, three-part horizontal division with the same height of upper and lower friso, sometimes one of them goes beyond other one [20].

2. Chronologically, the next period, dated 1880 s- 1899 , is characterized by widespread practice of retro style imitation, styles mixing, as well as appearing of stylistically new protosecession decoration style. However, typical decoration elements are still using. Numerous examples of forged decoration, dated that period, indicate that forging in Stanislaviv was still developed and was not supplanted by the casting technique.

In the age of stylistic variety, in the late XIX century, and imbricate housebuilding together with dominating of facade frontal composition (facade becomes a concentration place of all kinds of plastic and architectural decoration), art objects of forging and casting become the unchallengeable key elements of decoration. Art objects of forging and casting become signs indicating the historic style of the house, and become decorative accents of the buildings [20].

On the building № 6 at Mazepa Str. (1885) [17] we can find partly saved elements of the complex architectural environment, created by artists and architects, the leading role of which performs architectural-artistic metal. On the exterior it is demonstrated by balcony fencing and brackets on the main façade and door grating on the backside façade. In the interior: compound-section staircase footing made in casting technique, decorated with floral ornament and topped with capitals; staircase fencing of outhouse. By the example of this building, we can see that the tradition of artistic casting technique, demonstrated on façade by the balcony fencing and in the interior - by staircase footing, was kept while 1880s. Other decorative-structural elements were made by forging and stamping.
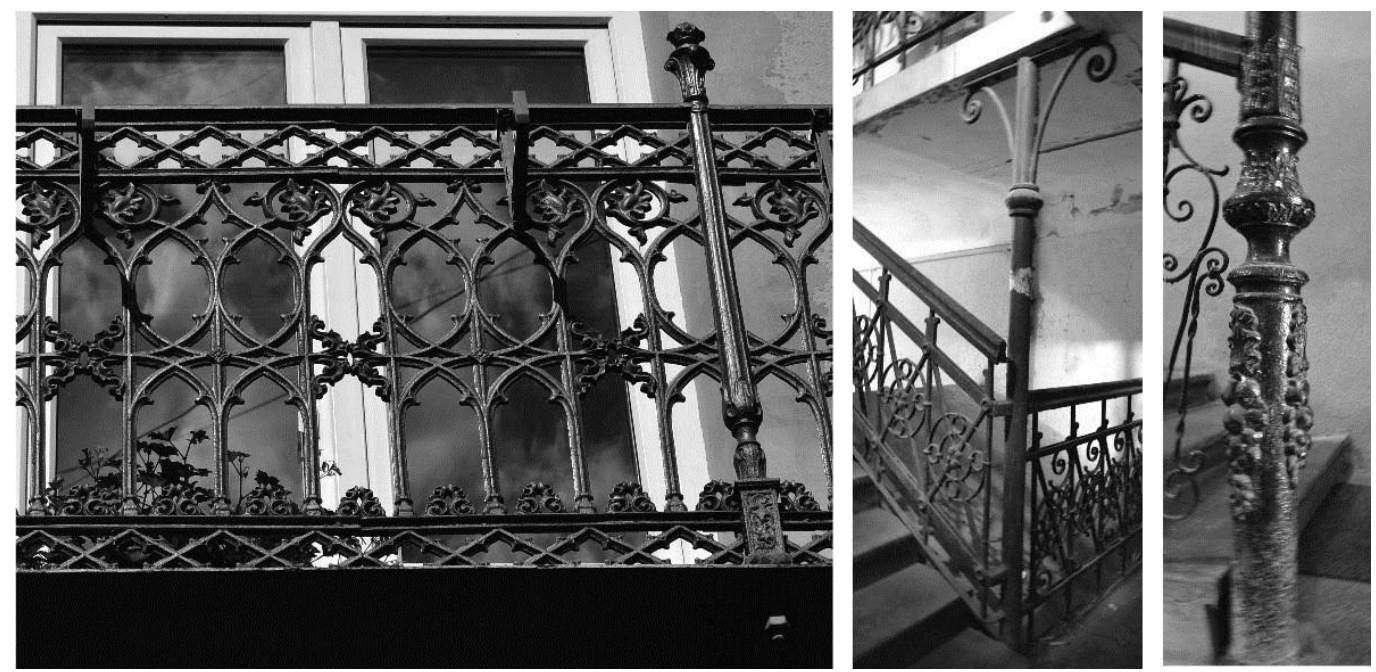

Fig. 5. Balcony fencing and brackets; staircase fencing; fragment of the decoration of staitcase footing in the house №6 at Mazepa Str. (dated 1885)

In Stanislaviv the forged architectural decoration with the stylistic features of past eras could be found on numerous residential and public buildings of those days, for example, on the house № 26 at Sichovyh Striltsiv Str. (1894), on the building № 104 at Shevchenko Str. (1896), on the house № 12 at Market Square (1880). 


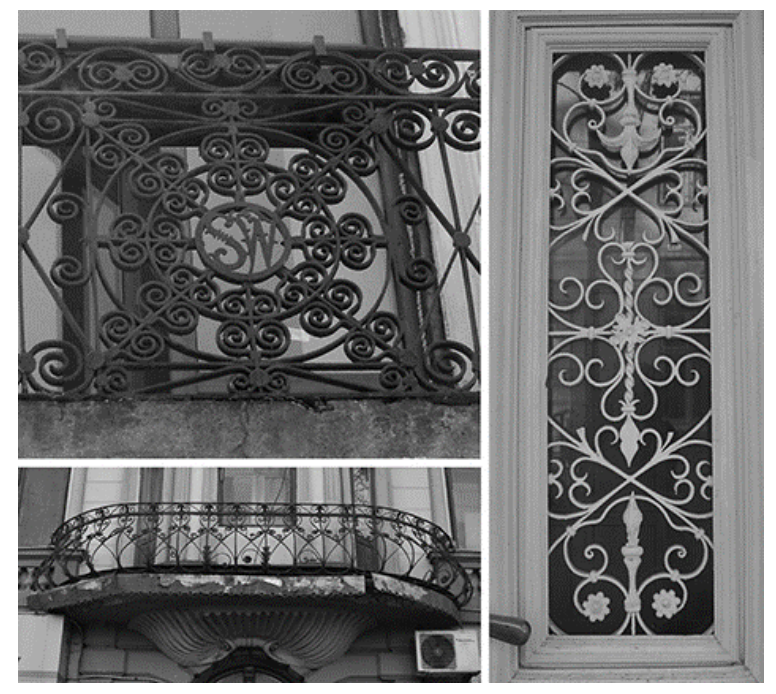

Fig. 6. Balcony fencing on the house № 26 at Sichovyh Striltsiv Str. (dated 1894); on the building № 12 at Market Square (1880); metal-plastic of door panel on the house № 104 at Shevchenko Str. (1896)

Often, metal decoration, for various reasons, was placed on the façade quite later then house was built. We can see such metal-plastic examples on the balcony of the building situated at 5 , Nezalezhnosti Str. (building of the house ended in 1870s) made in late historicism style while 1880s. This is confirmed by owner's initials shown on the monogram. Another example we can find on the balcony of the house № 2 at Nyzova Str. (building of the house ended in 1840), this fencing was made in 1895, confirmed by the owner's monogram «BZ» situated on compositional axis of the balcony (Bank Zaliczkowy, who bought the house in 1895) [18].

The influence of new art, in particular, its first aesthetic reproduction in metal-plastic pieces, represented on Stanislaviv buildings, is classified as protosecession decoration. Works, belonging to this group, clearly reflects the fight between a new aesthetic and eclecticism in architecture, also reflects contrast of decorative and rational, old and new, accenting on the individual character and compositional diversity. The originality of authors' creative activity, first of all, involved reference to a variety of sources: natural forms; mythology; traditional and folk decorative arts of different countries, particularly the Far-East; aesthetic of contemporary engineering constructions; rethinking and transformation of methods used in different historical styles. Free handling with the forms of different historical periods was enabled, by using secession stylization, to create a new palette of forms, also in regards to metal-plastic, for example exotic and grotesque elements. The widespread reference to medieval and gothic art and architecture, inherited from historicism, was fundamentally different. It involved borowing of not only romantic features, but also the principle of organic unity of the functions, such as constructive, decorative, utilitarian and aesthetic. For example, a balcony fencing form is subordinated to a balcony plate plastic in a house situated at 10, Mazepa Str. (1896); elegant lace of the decorative elements of staircase grating in the house № 11 at Mazepa Str. (1890). These examples reflect professionaly interpreted motifs of previous eras associated with jewelry.

So, in the late XIX century we can observe partial preservation of traditions of the second half of the century, followed by spreading of european (Vienna, Cracow, Lviv) effects of the new secession style. Stylistic trends of architectural-artistic metal, prevailed at that time and developed the tradition of historicism, play focusing role on the facades of buildings, belonging to the different typological groups. Often we can see that architectural-artistic metal contrasts with stylistic type of the building and becomes dominant. In the compositional structure dominated linear rhythm, three-part division, different types of symmetry. Ornamental decor includes geometric and floral motifs, such as: rings; spirals; flowers; leaves, branches and grapes. Technically artistic forging begins to dominate. 


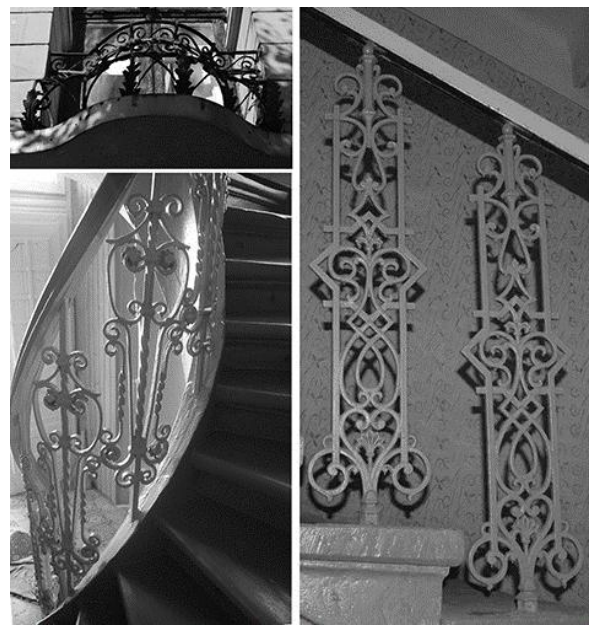

Fig. 7. Balcony fencing situated on the house № 10 at Mazepa Str. (1896), staircase fencing in the building № 102 at Shevchenko Str. (1896-1897) and in the building № 11 at Mazepa Str. (1890)

3. The third step, dated 1900-1914, chronologically complied with early and high stages of Stanislaviv secession development, and also with its rationalization in the later period. New style - secession includes all kinds of art, among them architectural metal, that acquired new meaning. Artistic metal in architecture of Stanislaviv dated early XX century, from one side, becomes the logical continuation of creative research from the late XIX century. On the other side, new principle of metal-plastic secession lies in consideration of the physical properties of metal-melting and hardness, to use them as a method of artistic expression. Boundaries between the decorative and structural were blended. Constructive architectural detail acquires a new function - decorative, combined with decorative plastic and therefore becomes an element of decoration.

Architects and blacksmiths, captured by possibilities of new constructions, demonstrated virtuosic working knowledge. They diversify decorative and functional forms, for example by making forged fencing in the form of interweaving halms. Researchers combined different directions of secession metal into two groups: linear decorative composition and linear decorative composition with shape elements, made of thin forged or extruded metal sheets. Delicate graphics of metal products in secession architecture become its dominant principle [21].

Most part of preserved architectural details are represented by balcony and staircase fencing, brackets, gates, basement windows grating, for example in buildings situated at: 13 and 38, Hrushevsky Str. (early XX century); 16, Tarnavsky Str. (1905-1906); 9, Chopin Str. (1909-1910) [18] and others. Technically difficult «belgian line», that becomes new style mark, was widely used in metal decorations of Stanislaviv, for example, door grating and staircases fencing in houses № 1 (1910), № 3 (1912), № 8 (1908) at Hrushevsky Str. Secession symbolism is represented by such example as «omega» letter, meaning the beginning and the end (is situated on the balcony fencing of the building № 9 at Hrushevsky Str., dated 1902), also solar signs, situated on a house № 8 at Kurbas Str. (1906).

In the early XX century artistic metal gives houses an individual uniqueness thanks to which such buildings become art objects, different from replicated ones. Geometric, plant and technical forms are used in ornamentation. The most stable of them is the spiral motif that resembles letters $\mathrm{C}, \mathrm{S}, \mathrm{X}$, and combinations of them. Often they are added by curls and contrasting straight lines. Among the plant forms dominated exotic and wild flowers, buds, grapes, sunflowers, fruits, roses, lilies, wedges transformed into palmetto, halms and leaves of acanthus [20].

Among zoomorphic motifs, most popular for artistic metal in architecture of Stanislaviv, are: butterflies, dragonflies, scorpions. Beyond bio- and zoo-morphism, widely were used symbolic forms, like waves, rays, flame [22].

In general, the composition of artistic metal works, dated early XX century, is characterized by dynamic, asymmetry, rhythmic order, complicated metric sets, form graphic. 


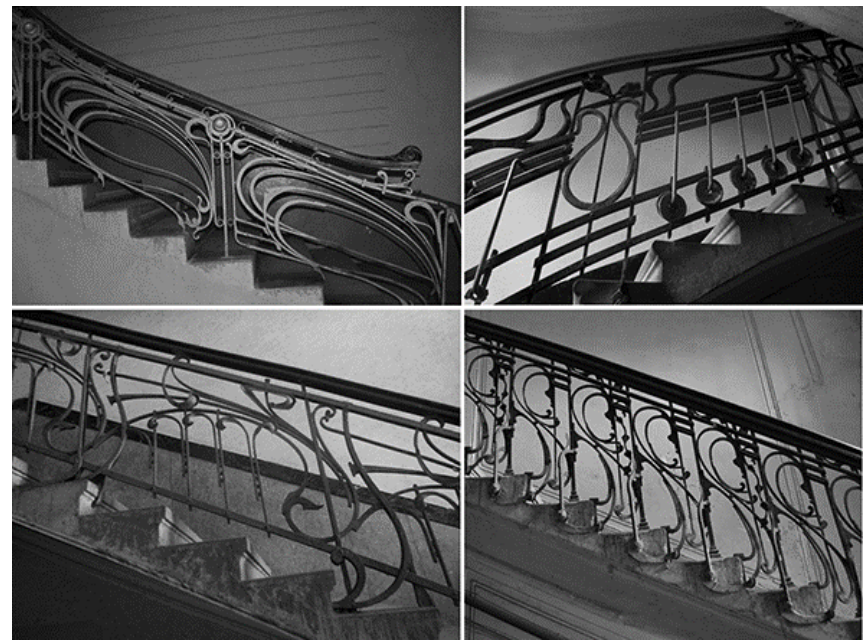

Fig. 8. Staircase fencing in the building № 26 at Chornovil Str. (1906); house № 5 at Vasylianky Str. (1911); house № 3 at Garkusha Str. (1912); building № 1 at Hrushevsky Str. (1910)
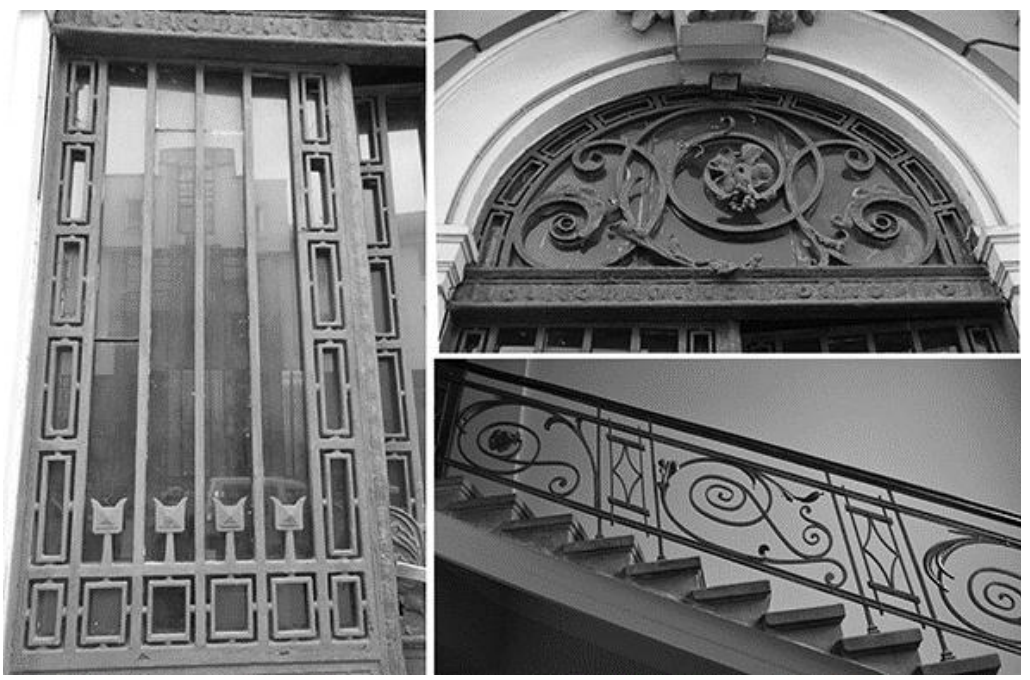

Fig. 9. Door grating, decorated window overpanel, staircase fencing in the house situated at 31, Hrushevsky Str. (1912)

\section{Conclusion}

Holding the perfect artistic feel, Stanislaviv masters of forging and casting art were able to combine highly artistic metal-plastic products with architecture and created a unique image of the historic city. Historical balconies, made in casting and forging technique, decorative window and door grating, gates, delicate attics should become samples for nowadays craftsmen and blacksmiths. Each year, through physical degrading and due to non-professional repairs, in common with indifferent attitude of the inhabitants of the historic buildings of Ivano-Frankivsk, the number of authentic architectural-artistic metal samples on the facades and interiors is radically going to fall off. To prevent this process, at first, we should make research work to identify, attribute, determinate technical condition, develop art-history study of all architectural-artistic complex of art metal represented in historic part of the town. The only way, leading to preservation of artistic metal as an object of cultural heritage, consists of the development and implementation of conservation, restoration, reproduction of lost fragments of metal-plastic parts or a whole object. All this could be realized by using scientifically-based methods used in modern European and world practices, also by implementation of actions concerning protection and harmonious coexistence of modern architectural metal decor on the historic buildings of the town. 


\section{Referenses:}

[1] Noha, O. (2009). Ivan Levynskyi arkhitektor, pidpryiemets, metsenat. Tsentr Yevropy, 191.

[2] DAIFO. F. 263. Op. 1. Spr. 721.

[3] DAIFO. F. 263. Op. 1. Spr. 1181.

[4] DAIFO. F. 263. Op. 1. Spr. 1199.

[5] DAIFO. F. 6. Op. 2. Spr. 67.

[6] DAIFO. F.27. Op. 1. Spr. 322.

[7] DAIFO. F.2. Op. 6. Spr. 558.

[8] DAIFO. F. 2 Op. 10. Spr. 3.

[9] DAIFO. F. 2. Op. 13. Spr. 656.

[10] DAIFO. F. 6. Op. 2. Spr. 127.

[11] DAIFO. F. 2 Op. 13. Spr. 54.

[12] DAIFO. F. 2. Op. 13. Spr. 633.

[13] DAIFO. F. 2 Op. 10. Spr. 3.

[14] DAIFO. F. 2. Op. 13. Spr. 797.

[15] DAIFO. F. 2. Op. 7. Spr. 1048.

[16] Sapak, N. V. (2011). Deiaki aspekty rozvytku khudozhnoho metalu KhIKh - pochatku XX stolittia na prykladi arkhitektury mista Mykolaieva. Obrazotvorche mystetstvo, 4, 144-147.

[17] Holovatyi, M. I., Fedunkiv, Z. B. (2010). Pamiatky arkhitektury Ivano-Frankivska: slovnyk do Zvodu pamiatok istorii ta kultury Ukrainy. Ivano-Frankivska oblast. Ivano-Frankivsk, 50.

[18] Ogłoszenie (1895). Kurjer stanisławowski, 14.

[19] Bonkovska, S. M. (1991).Kovalstvo na Ukraini (XIX-pochatok KhKh st.). Kyiv: Naukova dumka, 110.

[20] Mogilevskij, V. Ju. (1990). Hudozhestvennyj metall v arhitekture Kieva serediny XVII - nachala XX st. Moskovskoe vysshee hudozhestvenno-promyshlennoe uchilishhe (b. Stroganovskoe). Moscow, 21.

[21] Studnitska, M. (2014). Syntez mystetstv u hromadskii i zhytlovii arkhitekturi Halychyny pershoi tretyny KhKh stolittia. Ukrainske mystetstvoznavstvo: materialy, doslidzhennia, retsenzii, 14, 158-177.

[22] Komar, Zh. (1997). Metaloplastyka v arkhitekturi Stanislava pochatku XX st. Svoia khata, $1-2,18-20$. 